\title{
Removal of Cadmium Ions from Aqueous Solutions Using Flax Seeds as an Adsorbent
}

\author{
Nidaa Adil Jasim¹, Tamara Kawther Hussein ${ }^{2}$ \\ ${ }^{1}$ Department of Highway and Transportation Engineering, College of Engineering, AL-Mustansiriyah University, \\ ${ }^{2}$ Department of Environmental Engineering, College of Engineering - AL-Mustansiriyah University
}

\begin{abstract}
Removal of Cd(II) from aqueous solution through adsorption using flax seeds was studied. Adsorption parameters such as $\mathrm{pH}$, adsorbent particle size, adsorbent dosages, and initial concentrations of metal ions were studied. All experiments were conducted at room temperature. Langmuir and Freundlich adsorption isotherm models were applied to describe the quantitative uptake of $\mathrm{Cd}(\mathrm{II})$ ions by adsorbent. The results show that the maximum adsorption removal reach to $77 \%$ for $\mathrm{Cd}$ (II) onto flax seeds, at optimum operating conditions: $\mathrm{pH}$ of 5 , particle size of $75 \mu \mathrm{m}$, adsorbent dosage of $2 \mathrm{~g} / 100$ $\mathrm{ml}$ and metal concentration of $5 \mathrm{mg} / \mathrm{L}$. The equilibrium adsorption data for $\mathrm{Cd}(\mathrm{II})$ were better fitted to Freundlich adsorption isotherm model than Langmuir. The study concludes that the use of flax seeds as an economic and locally adsorbent for removing $\mathrm{Cd}$ (II) from polluted solution is effective. Thus offering a low cost material show potential use it to remove heavy metals.
\end{abstract}

Keywords: Flax Seeds, Adsorption, Cadmium, Adsorption Isotherm.

Paper history:(Received:17-1-2018; Accepted 19-7-2018)

\section{Introduction}

Heavy metals when they present in the environment is a complex problems due to their harmful effect. Many kinds of industries, mining and agriculture are discharge polluted and toxic wastewater[1]. In general, cadmium is the major available type of heavy metal in the aquaticenvironment, and cadmium recognized as a toxic and posing widespread threat to humans and wildlife, cause cancer,lung insufficiencybone lesions, hypertension and cause of renal disturbances[2]. Cadmium drain to the environment from many industrial wastes such as cadmium-nickel batteries, mining, dyes, alloy manufacturing, electroplating,

Plastic and pesticides $[3,4,5]$. The treatment of polluted water or industrial wastewater is the major concern of researchers. Adsorption technique has strongly used to remove the heavy metals especially $\mathrm{Cd}(\mathrm{II})$ ions from industrial wastewater.

Granular activated carbon (GAC) is an active material for adsorption process to remove heavy metals, by using a biofilm attached to GAC, the adsorption of metal by gram of GAC can be increase[6].Still there is a need for locally available, cheap and natural waste. Many corps like wheat, flax, sunflowers and potato can accumulate amount of $\mathrm{Cd}$ that present in soil, however it can be used for adsorption process[7], Different low cost adsorbents were suggested by many researches [8,9], still there is a necessity to find a convenient materials as an adsorbent to uptake cadmium from wastewater $[10,11,12]$. The maximum adsorption for cadmium was $99 \%$ when barley hull ash was used as an adsorbent [13]. Sugar cane bagasse are an agricultural waste produced, has given good adsorption capacity for cadmium from which the adsorption rate depended on agitation rate, $\mathrm{pH}$ and contact time[14]. Minerals, like clay, also, could be used as a natural resource and low cost adsorbent, the experiments of cadmium adsorption onto clay succeeded with low concentration ranges for cadmium[15,16]. Defatted flax seeds was recycled to remove organochlorine compounds and the results were effective[17]. This is because of the flax seeds is a highly berserk fiber, so that it receives the higher accumulation of $\mathrm{Cd}$ and adsorption onto it, either due to acidification or ionic exchange[18].In order to describe the adsorption process many models have been utilized like Freundlich and Langmuir models [19]. Isotherm models was used to evaluate cadmium adsorption onto ground pine cone([6].From these models the adsorption capacity, intensity, the maximum amount of intensity, and the adsorption affinities between the adsorbent and the adsorbate could be depicted. The goal of this paper is to study the potential utilization of flax seeds in the removal of $\mathrm{Cd}$ (II) ions from aqueous solutions by adsorption process depending on many factors, and to represent the equilibrium isotherm models.

\section{MATERIALS AND METHODS}

\section{Materials \\ Adsorbents Preparation}

Flax seeds was purchased from herpes shop, washed with tap water and distilled water many times. The wetted flax seeds were dried in oven at $150{ }^{\circ} \mathrm{C}$ for 2 hours. The dried flax seeds were grounded into powder by house blender and sieved to the desired particle size for experimental uses. Table 1 shows the chemical compositions of flax seed, which it constitutes from linoleic acid (fatty acid), carbohydrates (organic lignin), fiber (cellulose), protein and phenolic acid, each of these components belongs to an organic component. These components have carboxylic, phenolic and hydroxyl functional groups and they are able to react with the adsorbete molecules[20,21]. 
Table 1: Composition of Flax Seeds

\begin{tabular}{|c|c|}
\hline composition & amount \\
\hline $\begin{array}{c}\text { Moisture } \% \\
\text { Protein }\end{array}$ & $\begin{array}{c}4.23 \\
21-30 \mathrm{~g} / 100 \mathrm{~g}\end{array}$ \\
\hline Fat & $38-40 \mathrm{~g} / 100 \mathrm{~g}$ \\
\hline Ash & $3.45 \mathrm{~g} / 100 \mathrm{~g}$ \\
\hline Fiber(cellulose,lignin) & $28 \mathrm{~g} / 100$ \\
Linolenic acid(fatty acid) & $23 \mathrm{~g} / 100 \mathrm{~g}$ \\
Carbohydrates & $29 \mathrm{~g} / 100 \mathrm{~g}$ \\
Phenolic acid & $1 \mathrm{~g} / 100 \mathrm{~g}$ \\
\hline $\mathrm{Fe}$ & $5-6 \mathrm{mg} / 100 \mathrm{~g}$ \\
\hline $\mathrm{Zn}$ & $4.43 \mathrm{mg} / 100 \mathrm{~g}$ \\
\hline $\mathrm{Cu}$ & $1.9 \mathrm{mg} / 100 \mathrm{~g}$ \\
\hline $\mathrm{Ca}$ & $236.4 \mathrm{mg} / 100 \mathrm{~g}$ \\
\hline $\mathrm{Na}$ & $27-30.12 \mathrm{mg} / 100 \mathrm{~g}$ \\
\hline $\mathrm{Mg}$ & $422.5 \mathrm{mg} / 100 \mathrm{~g}$ \\
\hline $\mathrm{Mn}$ & $2.73-3 \mathrm{mg} / 100 \mathrm{~g}$ \\
\hline $\mathrm{K}$ & $882 \mathrm{mg} / 100 \mathrm{~g}$ \\
\hline
\end{tabular}

\section{Adsorbent Characteristics}

The pore structure and images of the powdered samples before and after $\mathrm{Cd}(\mathrm{II})$ adsorption were observed using a scanning electron microscope (SEM), model AIS2300C (USA), Angstrom Advanced, coated with gold. FTIR spectra analysis was difficult to done because the grounded flax seed is greasy.

\section{Adsorbate Solution}

$1000 \mathrm{mg} / \mathrm{L}$ stock solution of $\mathrm{Cd}(\mathrm{II})$ ions was prepared. $2.036 \mathrm{~g}$ of pure saltCdCl $\mathrm{Cl}_{2} .2 \mathrm{H}_{2} \mathrm{O}$ has dissolved in $1 \mathrm{~L}$ of deionised water and used for all experiments with required dilution. $\mathrm{Cd}(\mathrm{II})$ ions in the solutions after equilibrium were determined by AA-6200 Atomic adsorption flame emission spectrometer (Shimadzu, Japan).

The removal efficiency ( $\mathrm{R} \%$ ) of $\mathrm{Cd}(\mathrm{II})$ was calculated for each run as follows:

$$
R(\%)=\frac{\left(C_{o}-C_{e}\right)}{C_{e}} \times 100
$$

where $\mathrm{C}_{\mathrm{o}}$ and $\mathrm{C}_{\mathrm{e}}$ are initial and equilibrium concentrations. The equilibrium adsorptions $\mathrm{Cd}(\mathrm{II})$ by adsorbents were calculated as follows[22]

$q_{e}=\frac{\left(C_{o}-C_{e}\right) \times V}{m}$ where, $\mathrm{q}_{\mathrm{e}}$, the equilibrium adsorption capacity $(\mathrm{mg} / \mathrm{g}) ; \mathrm{C}_{\mathrm{o}}$ and $\mathrm{C}_{\mathrm{e}}$ are the initial and the equilibrium concentrations, $(\mathrm{mg} / \mathrm{L}) . \mathrm{V}$ is the volume of solution $(\mathrm{L})$, and $\mathrm{m}$ is the adsorbent mass $(\mathrm{g})$.

\section{Methods}

\section{Effect of $\mathbf{p H}$}

The effect of $\mathrm{pH}$ on $\mathrm{Cd}(\mathrm{II})$ adsorption onto flaxseeds was studied, thus, the dosage flaxseeds was $2 \mathrm{~g} / 100 \mathrm{ml}$, and particle size $150 \mu \mathrm{m}$, while, $\mathrm{pH}$ was ranged from 2 to 8 of the samples using $0.1 \mathrm{M} \mathrm{H}_{2} \mathrm{SO}_{4}$ and $0.1 \mathrm{M} \mathrm{NaOH}$ and measured with $\mathrm{pH}$ meter type (3110,WTW,Germany). Cd(II) concentrations was $5 \mathrm{mg} / \mathrm{L}$ for all solutions during the experiments. Samples were agitated in shaker (GEMMY orbit shaker, model VRN-480) for a period equal to 3 hours with $200 \mathrm{rpm}$ (until equilibrium was reached), thereafter, samples were left in contact with adsorbent for 24 hours filtered with filter paper ( Whatman filter $\mathrm{GF} / \mathrm{C}(1.2 \mu \mathrm{m}))$ in order to analyze them.

\section{Effect of Particle Sizes}

Flax seeds were grounded and sieved with standard sieves in order to fit the desired particle size $(75,150,300$ and $600 \mu \mathrm{m})$, each size was included in batch test. Tests were carried out in five sets of flasks with $100 \mathrm{ml}$ volume contained distilled water, $2 \mathrm{gm}$ of flax seeds, $5 \mathrm{mg} / \mathrm{L} \mathrm{Cd}$ concentration and $\mathrm{pH}$ 5, were shaking with $200 \mathrm{rpm}$ for 3 hours. Samples were left in contact with adsorbent for 24 hours, and then filtered with filter paper in order to analyze them.

\section{Effect of Adsorbent Dosage}

The impact of the adsorbent amount on the equilibrium adsorption for each $\mathrm{Cd}(\mathrm{II})$ were investigated with flax 
seeds of $0.5,1,2,3$ and $4 \mathrm{~g}$ in six sets of $100 \mathrm{ml}$ water, was contain cadmium with $5 \mathrm{mg} / \mathrm{L}, 75 \mu \mathrm{m}$ and 5 for concentration, particle size and $\mathrm{pH}$. The samples were shaken for 3 hours at speed of $200 \mathrm{rpm}$ at room temperature. Samples were left in contact with adsorbent for 24 hours, and then filtered with filter paper in order to analyze them and then applying the Langmuir and Freundlich adsorption isotherms.

\section{Effect of Metal Ions Concentrations}

Different Cd(II) ions solutions were prepared, the initial concentrations were as follows 2.5, 5, 10, 15, 20 and 30 $\mathrm{mg} / \mathrm{L}$, in order to study the initial concentration effect, at room temperature and optimum conditions obtained previously to apply the Langmuir and Freundlich adsorption isotherms.

\section{RESULTA AND DISCUSSION}

\section{Structure Of Flaxseeds (SEM)}

In the SEM (Figure 1) of flax seeds composite, the images at higher magnification ( before and after ) give an idea of the morphology and size of the particles. It is clearly show that flax seeds particles have a rough surfaces, which give more surface area[22]. In general after $\mathrm{Cd}(\mathrm{II})$ has been adsorbed, the morphology of the surface changed. The uptake of $\mathrm{Cd}(\mathrm{II})$ ions onto the adsorbent can be seen as porous.
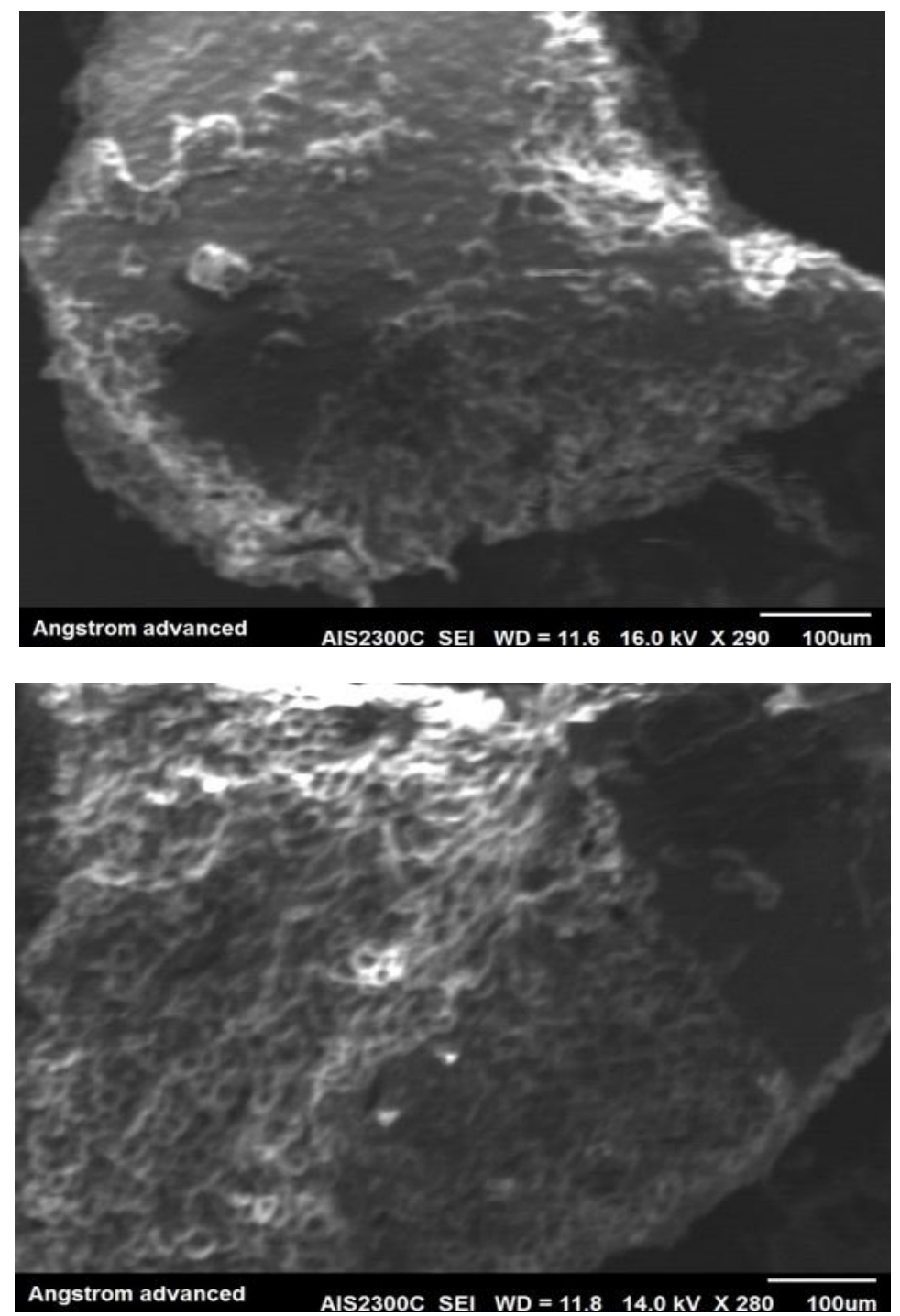

\section{Optimum pH Results}

Adsorption of metal ions onto adsorbent is related to $\mathrm{pH}$ of aqueous solution. Many tests of $\mathrm{pH}$ from 2 to 8 were carried out. In general, Figure 2 shows the adsorption of $\mathrm{Cd}(\mathrm{II})$ onto flax seeds is low at $\mathrm{pH} 2$,
Figure1: SEM image of flaxseeds before (up) and after (down) adsorption

thereafter, it increased to reach its maximum value at $\mathrm{pH}$ 5 , however it decreased to a constant rate at $\mathrm{pH} \mathrm{6,7}$ and 8 . The adsorbent components have the ability of donation of an electron pair to form complex with metal ion, or bind heavy metals by exchange of hydrogen ions for metal ions, the chemical composition of flax seeds 
facilitate of the adsorption process ${ }^{(23)}$. At low $\mathrm{pH}$, protons compete with metal ion for sorption sites on the adsorbent surface [24]. On the other hand, the greatest cadmium removal was at $\mathrm{pH} 5$ and at higher $\mathrm{pH}$, the lower number of $\mathrm{H}^{+}$with higher surface negative charge results in more cadmium adsorption ${ }^{(16)}$. When the aqueous medium became alkalinity medium, the adsorption decreased, because of some functional groups are deprotonated to release $\mathrm{H}^{+}$ions competing with $\mathrm{Cd}$ (II) ions to reduce the uptake process. Similar results were reported by other researches[8,25].

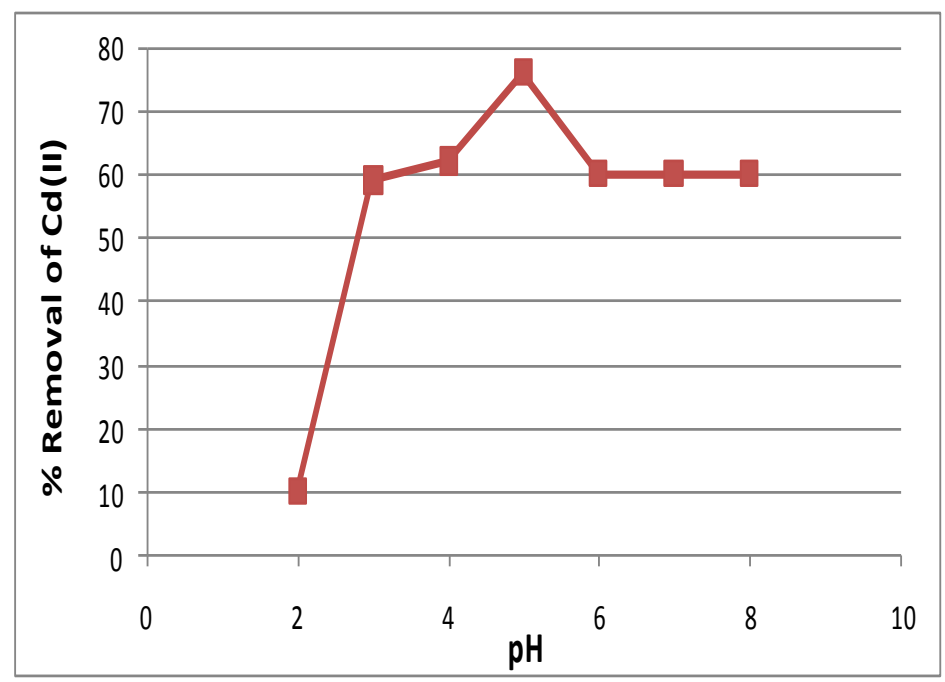

Figure2: $\mathrm{pH}$ effect on the percentage removal rate of $\mathrm{Cd}(\mathrm{II})$

\section{Optimum Particles Size Results}

Figure 3 shows that the rate of cadmium adsorption decreases with the increases of the flax seeds particle size, hence, the percentage removal of $\mathrm{Cd}$ (II) decreased from $75,70,55,50$, and $45 \%$ with increasing of the particle size to $75,150,300,425$, and $600 \mu \mathrm{m}$ respectively. This can be related to the fact that the particle size when decrease this will increase the surface area[11,16]

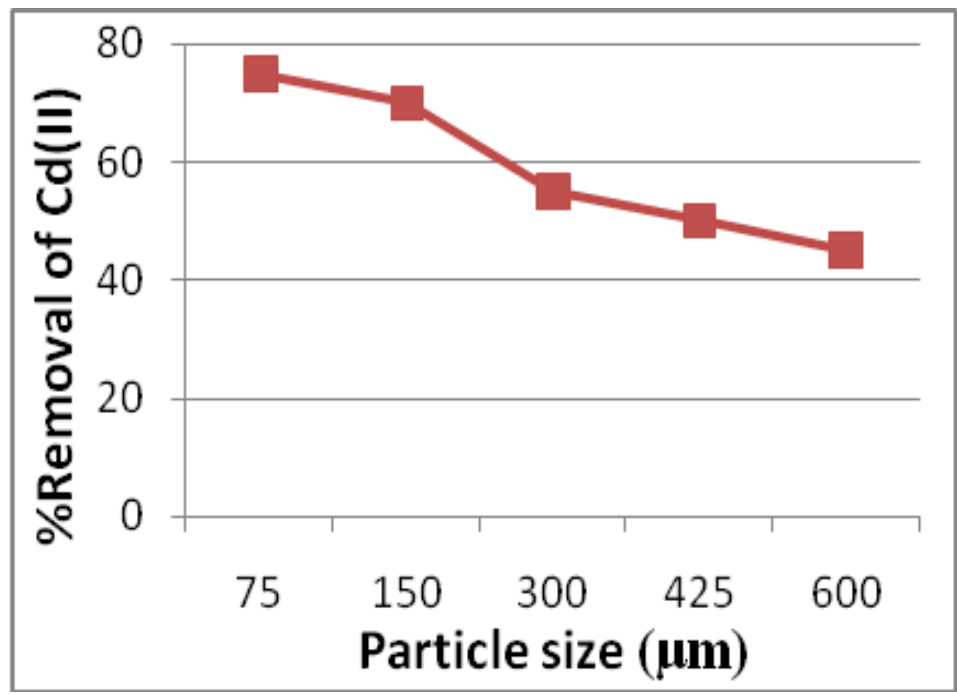

Figure3: Particle size effect on the percentage removal rate of $\mathrm{Cd}(\mathrm{II})$

\section{Optimum Adsorbent Dosage Results}

It is quite clear from Figure 4 that the optimum value of adsorbent dosage was between 1 to $2 \mathrm{gm}$ at $75 \%$ removal rate. Less removal rates were obtained for dosages less than $1 \mathrm{gm}$ and more than $2 \mathrm{gm}$. when the amount of adsorbent increased, adsorption of Cd (II) will increase, this is related to the increasing of large number of active surface area on the adsorbent when the adsorbent dosage increase[26]

However, when the adsorbent dosage increased, the percentage removal started to decrease with low concentrations while the ration between metal and 
adsorbent mass stayed constant, so, any addition of reached the same results[27, 28]. adsorbent is not effective. Other investigators were

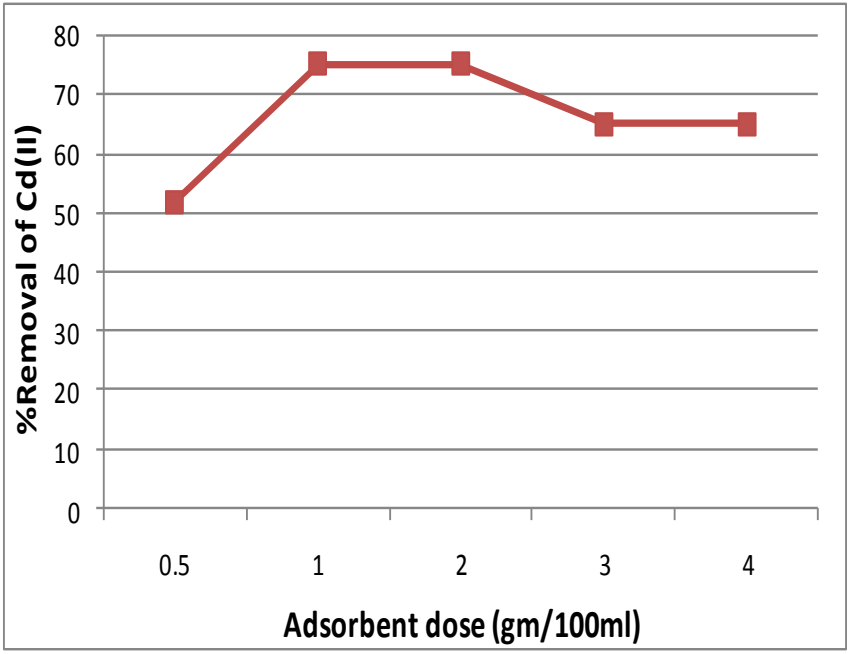

Figure 4: Adsorbent dosage effect on the percentage removal rate of $\mathrm{Cd}(\mathrm{II})$

\section{Optimum metal Ions Concentration Results}

In this study, the initial concentrations of $\mathrm{Cd}(\mathrm{II})$ were taken as $2.5,5,10,15,20$ and $30 \mathrm{mg} / 1$, at $\mathrm{pH} 5$ using 2 $\mathrm{g} / 100 \mathrm{ml}$ flaxseeds and $75 \mu \mathrm{m}$ particle size. Cd(II) ions analysis revealed that, the percentage removal was decreased from $77-69 \%$ when metal ions concentration increased from 2.5 to $30 \mathrm{mg} / \mathrm{l}$. However uptake of Cd (II) by unit weight of the adsorbent was increased (Figure 5). Similar observation was reported in many works[29]. In low concentration the removal efficiency is high, because the active adsorbent particles sites are limited and they can uptake a small number of metal particles. However, at high metal concentration the adsorbent particles active sites covered[11].

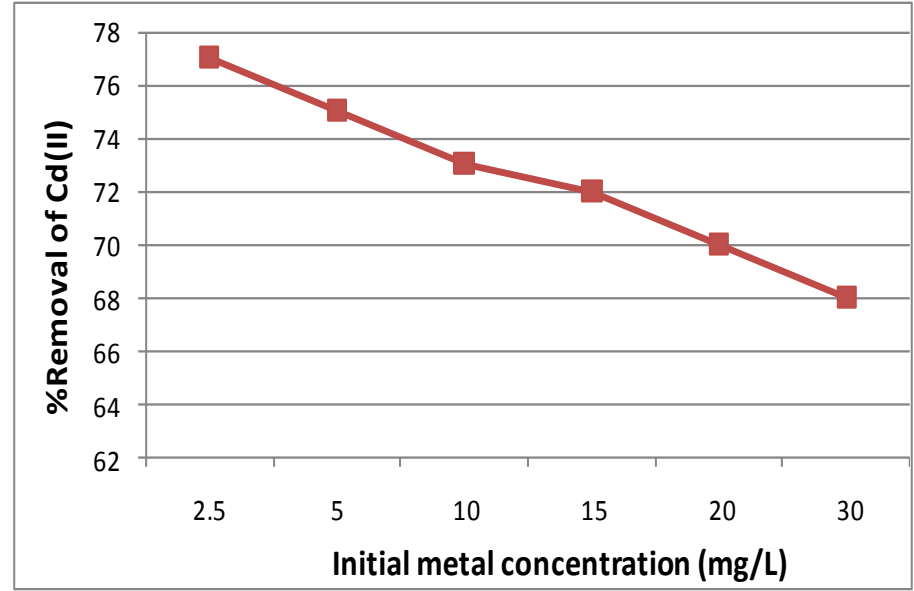

Figure5: Initial metal ions concentration effect on the percentage removal of Cd(II)

\section{Adsorption Isotherm}

Equilibrium uptake of $\mathrm{Cd}(\mathrm{II})$ was investigated with sorbent weight of $2 \mathrm{~g}$ of flax seeds in contact with 100 $\mathrm{mL}$ of solutions and at $\mathrm{pH} 5$. The flasks were shaken at $200 \mathrm{rpm}$ and the equilibrium concentration of the remaining $\mathrm{Cd}(\mathrm{II})$ was determined by atomic adsorption flame emission spectrometer. The analysis of the isotherm data is important to make models, actually represent the results. Two adsorption isotherms were used to fit the equilibrium data using Langmuir and Freundlich models.

\section{Langmuir Isotherm}

Lamgmuir model is suitable for studying the monolayer adsorption, because the process is take place at homogeneous sites. Constant energy process and there is a saturated monolayer of adsorbate molecules on the adsorbent particle surface [30, 31].

.The Langmuir model is: 
$q_{e}=\frac{q_{m} K_{L} C_{e}}{1+K_{L} C_{e}}$

where $C_{\mathrm{e}}$ is the equilibrium concentration $(\mathrm{mg} / \mathrm{L}), \mathrm{q}_{\mathrm{e}}$ is the amount adsorbed at equilibrium $(\mathrm{mg} / \mathrm{g}), \mathrm{q}_{\mathrm{m}}$ is the maximum amount of adsorption on the adsorbent surface $(\mathrm{mg} / \mathrm{g})$ and $\mathrm{K}_{\mathrm{L}}$ is the Langmuir constant $(\mathrm{L} / \mathrm{mg}$ ) related to energy adsorption capacity. Langmuir equation can be fitted with a straight line equation as follows:

$$
\frac{C_{e}}{q_{e}}=\frac{1}{K_{L} q_{m}}+\frac{C_{e}}{q_{m}}
$$

The values of $K_{L}$ and $q_{m}$ were calculated from the slope and intercept of the linear plots of $\mathrm{C}_{\mathrm{e}} / \mathrm{q}_{\mathrm{e}}$ versus $\mathrm{C}_{\mathrm{e}}$,
Langmuir adsorption can be clear up by means of $R_{L}$ and it is a constant that it could be concluded from it if the adsorption is favorable or not, it calculated by [32]:

$$
R_{L}=\frac{1}{1+K_{L} C_{o}}
$$

where $C_{o}$ is the initial $\mathrm{Cd}(\mathrm{II})$ concentration $(\mathrm{mg} / \mathrm{L})$. The favorable adsorption when $R_{L}$ values between 0 and 1 . The linear plot of the Langmuir isotherm for $\mathrm{Cd}$ (II) adsorption is shown in Figure 6 and Table 2 respectively. From tables, the maximum adsorption capacity, $\mathrm{q}_{\mathrm{m}}$, for complete monolayer coverage are found $7.57 \mathrm{mg} / \mathrm{g} . R_{L}$ value obtained is listed in Tables 2. $R_{L}$ value for the adsorption shows that the adsorption process favorable .$K_{L}$ obtained value is $0.022 \mathrm{~L} / \mathrm{g}$

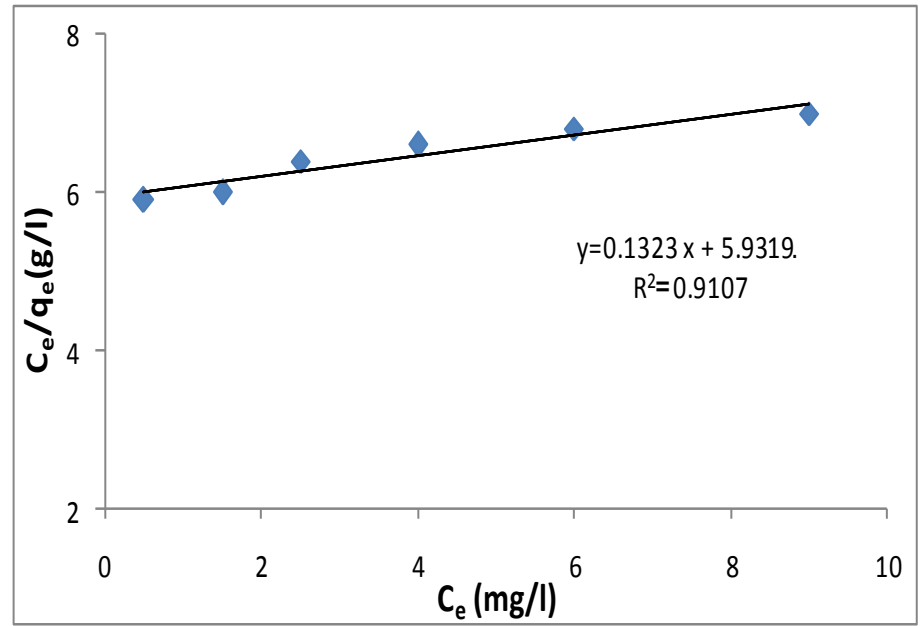

Figure 6: Langmuir adsorption models for Cd(II) on flax seeds.

\section{Freundlich Isotherm}

The Freundlich model is an equation depend on the adsorption on the heterogeneous surfaces. The Freundlich model can be expressed as [25]:

$\ln q_{e}=\ln K_{f}+\frac{1}{n} \ln C_{e}$

where $\mathrm{q}_{\mathrm{e}}$ mass of adsorbate is adsorbed per unit mass of adsorbent $(\mathrm{mg} / \mathrm{g}), \mathrm{C}_{\mathrm{e}}$ is the equilibrium concentration of adsorbate $(\mathrm{mg} / \mathrm{l}), K_{f}$ indicates adsorption capacity and $\mathrm{n}$ an intensity factor of the adsorption process, which varies with the heterogeneity of the adsorbent. The adsorption is better favorability when $1 / \mathrm{n}$ is to be greater. The fractional values of $1 / \mathrm{n}$ ranged between 0 and 1 . The constants $K_{f}$ and $1 / n$ were calculated from the intercept and slope of the plot of $\ln q e$ versus $\ln C_{e}$. Figure 7 shows the linear plot of Freundlich isotherm for adsorption of $\mathrm{Cd}(\mathrm{II})$ onto flax seeds. The calculated parameters are shown in Table 2. The Freundlich isotherm model was found best fitted with experimental data as the value of $\mathrm{R}^{2}$ equal to 0.99 (Table 2). $K_{f}$ is a Freundlich constant that shows the adsorption capacity on heterogeneous sites level. The adsorption intensity given by the Freundlich coefficient $(1 / n)$ is smaller than unit indicating the favorable adsorption[32]. These results indicate the Freundlich equation represents a better fit than Langmuir. The Langmuir equation is shown a homogeneous adsorption, while Freundlich equations is demonstrated a heterogeneous adsorption. The correlation coefficients are shown in Table $2 . R^{2}$ value of the Freundlich shows that the adsorption process is better in compared with values obtained from Langmuir plot, this indicate that the heterogeneous adsorption occurred on surfaces $[25,32]$ 


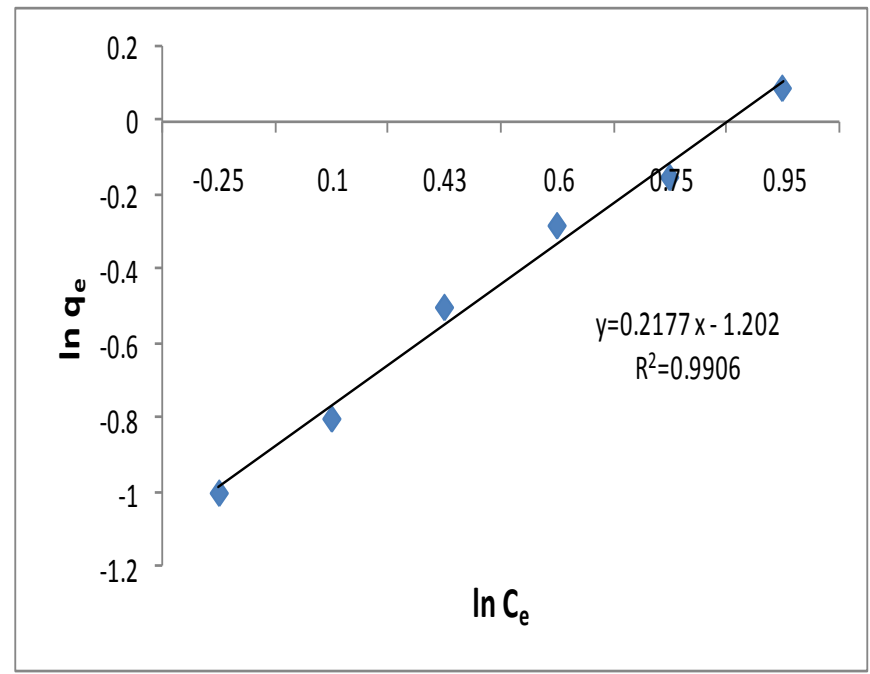

Figure7: Freundlich adsorption models for Cd(II) on flax seeds

Table 2: Langmuir and Freundlich isotherm parameters for Cd (II)

\begin{tabular}{|c|c|c|c|c|c|c|c|}
\hline Adsorbent & \multicolumn{3}{|c|}{ Langmuir model } & \multicolumn{3}{c|}{ Freundlich model } \\
\hline Flax seeds & $\begin{array}{c}\mathbf{q}_{\mathrm{m}}(\mathrm{m} \\
\mathrm{g} / \mathrm{g})\end{array}$ & $\mathrm{K}_{\mathrm{L}}(\mathrm{L} / \mathrm{mg})$ & $\mathbf{R}_{\mathrm{L}}$ & $\mathbf{R}^{2}$ & $\mathbf{n}$ & $\mathrm{K}_{\mathrm{f}}$ & $\mathbf{R}^{2}$ \\
\hline Parameters values & 7.57 & $\mathbf{0 . 0 2 2}$ & $\mathbf{0 . 9 8}$ & $\mathbf{0 . 9 1 0}$ & $\mathbf{4 . 6}$ & $\mathbf{0 . 3}$ & $\mathbf{0 . 9 9 0}$ \\
\hline
\end{tabular}

\section{CONCLUSIONS}

This study indicate that flax seeds have a good capacity of adsorption for $\mathrm{Cd}(\mathrm{II})$. The percentage removal depended on $\mathrm{pH}$, adsorbent particle size, adsorbent dosage, and adsorbate concentration,. The maximum adsorption capacity was found at $\mathrm{pH}$ 5, particle size $75 \mu \mathrm{m}$, adsorbent dosage $2 \mathrm{gm}$, and initial adsorbate concentration $2.5 \mathrm{mg} / \mathrm{L}$. The adsorption isotherms had fitted better with Freundlich equation compared with Lamgmuir equation. This material can be successfully used as an environment friendly product for removal of heavy metals from industrial wastewater.

\section{REFERENCES}

[1]. K.V. Gupta, M. S. Gupta, Process development for the removal of lead and chromium from aqueous solutions using red mud-an aluminum industry waste. Water Res. 35, , (2001), 1125-1134.

[2]. L.D. Mackenzie, A. David, "Cornwell. Introduction to Environmental Engineering" .McGraw. Hill international edition. $4^{\text {th }}(1997)$.

[3]. J. Wu,, J. Lu, T. H. Chen, Z. He., Y. Su., , and X. Y. Yao, In situ biotreatment of acidic mine drainage using straw as sole substrate, Environ. Earth Sci., 60, (2010), 421-429.
[4]. C. W. Cheung, J. F. Porter., and G. Mckay., Adsorption kinetic analysis for the removal of cadmium ions from effluents using bone char. Water Res., 35(3), .(2001), 605-612.

[5]. R. Salim, M. M. Al-Subu, and E. Sahrhage, ,Uptake of cadmium from water by beech leaves. J. Environ. Sci. Health., A27(3), (1992), 603-627

[6]. D. Tilaki, and R. Ali, Study on removal of cadmium from water environment by adsorption on GAC, bac and biofilter, Diffuse Pollution Conference Dublin , 8B Ecology:8-35 (2003)

[7]. C.A. Grant, W.T. Buckley, L.D. Bailey, and F. Selles, Cadmium accumulation in crops, canadian journal of plant science, agronomy section, (1997), 1-16

[8]. S. N. Farhan, Biosorbtion of Copper and Lead ions Using Wheat Husk, Second Engineering Scientific Confrence, 4, (2015), 835-845.

[9]. S. N, Farhan, and A.. A. Kadam, Biosorbtion of Heavy Metals from Aqueous Solution by Saccharomyces Cerevisiae, International Journal of Industrial Chemistry", 6(2), (2015), 114-130.

[10].H. Izanloo ,and S. Nasseri, "Cadmium Removal from Aqueous Solutions by Ground Pine Cone", Iranian J Env Health SciEng, 2(1), (2005), 33-42 . 
[11]. K. Parmar, K., Removal of cadmium from aqueous solution using cobalt silicat precipitation tube (cospt) as adsorbent, International journal of science invention today, 2(3), (2013), 204-215

[12]. G. Venkatesan, and U. Senthilnathan, May, Adsorption Batch Studies on the Removal of Cadmium using Wood of Derris Indica based Activated Carbon, Research Journal of Chemistry and Environment, 17 (5), (2013)

[13]. A. Maleki, A. H. Mahvi, M. A. Zazouli, H. Izanlooand, and A. Hoshangbarati, Aqueous cadmium removal by adsorption on barley hull and barley hull ash, Asian journal of chemistry, 23 (3), (2011), 1373-1376

[14]. S. C. Ibrahim, M. A. K.. M. Hanafiah, and M. Z. A. Yahya, Removal of Cadmium from aqueous solution by adsorption onto Sugarcane Bagasse, American Eurasian J. Agaic and Environ Sci., 1(3): 179184.(2006)

[15]. Y. C. Sarma, and V. Srivastava, Adsorption of cadmium(II) from aqueous solution by an indigenous clay mineral", Indian Journal of Chemical Technology. 13, .(2006), 218-221.

[16]. S. S. Al-Shahrani, Removal of cadmium from waste water using Saudi activated bentonite, Waste Management and the Environment VI, 163, .(2012), 391-402.

[17]. A. Adachi, T. Komiyama, T. Tanaka, M. Nakatani, R. Muguruma, and T. Okano, Removal efficiency of defatted seed for organochlorine, journal of health science, 1. 47(1), (2001), 54-59.

[18]. M. Callegaro, B. Milbradt, E. Alves, T. Diettrich, D. Kemerich, B. Hausen, F. Duarte, E. Flores, V. Dressler, and T. Emanuelli, Effect of wheat bran and flaxseed on cadmium effects and retention in rats, Human and Experimental Toxicology, 30(8), .(2010), 981-991.

[19]. A.A. Hassan, and Z. A. S. Hassan, Methylene blue removal from aqueous solution by adsorption on eggshell bed, Euphrates Journal of Agriculture Science,.5 (2), .(2013), 11-23.

[20]. S. Hussain, F. M. Anjum, M. Butt, and M. A.Sheikh, Chemical compositions and functional properties of flaxseed flour, Sarhad J. Agric. 2(.4).(2008)

[21]. R. Bernacchia, R. Preti, G. Vinci, Chemical composition and health benefits of flax seed, Austin Journal of Nutrition and Food Sciences,.2 (8), (2014), $1-9$.

[22]. M. A. Hossain, H. H. Ngo, W. S. Guo, and T. V. Nguyen, Maech, biosorption of $\mathrm{Cu}(\mathrm{II})$ from water by banana peel based biosorbent: experiments and models of adsorption and desorption, Journal of Water Sustainability, 2 ( 1), (2012), 87-104.
[23].K. S. Rao1, M. Mohapatra, S. Anand, and P. Venkateswarlu, Review on cadmium removal from aqueous solutions, International Journal of Engineering, Science and Technology 2 (7), (2010) 81-103.

[24]. K. Mariadas, G. Kalyani, H. JogaRao,K. Y. Prasanna, and P. King, The removal and equilibrium studies of cadmium by natural clay as adsorbent, International Journal of Scientific \& Engineering Research, 3(8), .(2012), 2875-2882.

|[25]. A. Z. A, .Al Othman, A. Hashem, and M .A. Habila Kinetic equilibrium and thermodynamic studies of cadmium (II) adsorption by modified agricultural wastes, Molecules , 16, (2011), 10443-10456.

[26]. M. J. Amiri, E. Fadaei, A. Baghvand, and Z. Ezadkhasty, Removal of heavy metals Cr (VI), Cd (II) and Ni (II) from Aqueous Solution by bioabsorbtion of laeagnus Angustifolia, Int. J. Environ. Res., 8(2), (2014), 411-420.

[27]. A. Kakaei, and M. Kazemeini, Removal of Cd (II) in water samples using modified magnetic iron oxide nanoparticle, Iranian Journal of Toxicology, 10 (1), (2016), 9-14.

[28]. A. A. Giwa, I. A. Bello, M. A. Oladipo, and D. O. Adeoye, Removal of cadmium from waste-water by adsorption using the husk of melon (Citrulluslanatus) seed, International journal of basic and applied science, 2,(1), .(2013), 110-123

[29]. D. Balarak, H. Azarpira, and F. K. Mostafapour, Thermodynamics of removal of cadmium by adsorption on barley husk biomass, Der PharmaChemica, 8(10), (2016),243-247.

[30]. R. A. K. Rao, and M. Kashifuddin, Kinetics and isotherm studies of $\mathrm{Cd}(\mathrm{II})$ adsorption from aqueous solution utilizing seeds of bottlebrush plant (Callistemon chisholmii), Appl Water Sci, (2014) 4 371-383.

[31]. T. K. Hussein, "Comparative study for removal of $\mathrm{Zn}^{+2}$ ions from aqueous solutions by adsorption and forward osmosis", 18(2), .(2017), 125-138.

[32]. V. Singh, and S. K. Singh, Cadmium (II) removal from aqueous solution using guar gum- gum-silica nanocomposite, Advanced Materials Letters, .6(7), .(2015), 607-615. 